\title{
Detection of Bartonella tamiae, Coxiella burnetii and rickettsiae in arthropods and tissues from wild and domestic animals in northeastern Algeria
}

Hamza Leulmi ${ }^{1,2}$, Atef Aouadi $^{3,4}$, Idir Bitam ${ }^{1,2,5}$, Amina Bessas $^{2}$, Ahmed Benakhla ${ }^{3}$, Didier Raoult ${ }^{1}$ and Philippe Parola ${ }^{1 *}$

\begin{abstract}
Background: In recent years, the scope and importance of emergent vector-borne diseases has increased dramatically. In Algeria, only limited information is currently available concerning the presence and prevalence of these zoonotic diseases. For this reason, we conducted a survey of hematophagous ectoparasites of domestic mammals and/or spleens of wild animals in El Tarf and Souk Ahras, Algeria.

Methods: Using real-time PCR, standard PCR and sequencing, the presence of Bartonella spp., Rickettsia spp., Borrelia spp. and Coxiella burnetii was evaluated in 268/1626 ticks, 136 fleas, 11 Nycteribiidae flies and 16 spleens of domestic and/or wild animals from the El Tarf and Souk Ahras areas.

Results: For the first time in Algeria, Bartonella tamiae was detected in 12/19 (63.2 \%) Ixodes vespertilionis ticks, 8/11 (72.7 \%) Nycteribiidae spp. flies and in 6/10 (60 \%) bat spleens (Chiroptera spp.). DNA from Coxiella burnetii, the agent of $\mathrm{Q}$ fever, was also identified in 3/19 (15.8\%) I. vespertilionis from bats. Rickettsia slovaca, the agent of tick-borne lymphadenopathy, was detected in 1/1 (100\%) Haemaphysalis punctata and 2/3 (66.7 \%) Dermacentor marginatus ticks collected from two boars (Sus scrofa algira) respectively. Ri. massiliae, an agent of spotted fever, was detected in 38/94 (40.4\%) Rhipicephalus sanguineus sensu lato collected from cattle, sheep, dogs, boars and jackals. DNA of Ri. aeschlimannii was detected in 6/20 (30\%) Hyalomma anatolicum excavatum and 6/20 (30 \%) Hy. scupense from cattle. Finally, Ri. felis, an emerging rickettsial pathogen, was detected in 80/110 (72.7\%) Archaeopsylla erinacei and 2/2 (100\%) Ctenocephalides felis of hedgehogs (Atelerix algirus).
\end{abstract}

Conclusion: In this study, we expanded knowledge about the repertoire of ticks and flea-borne bacteria present in ectoparasites and/or tissues of domestic and wild animals in Algeria.

Keywords: Bartonella tamiae, Rickettsia, Coxiella burnetii, Ticks, Fleas, Algeria

\section{Background}

Since the beginning of the 20th century, ticks (Acarina), fleas (Siphonaptera) and other hematophagous arthropods have been implicated as vectors, reservoirs, and/or amplifiers of agents of human zoonoses [1]. Ticks are hematophagous arthropods that are considered second

\footnotetext{
* Correspondence: philippe.parola@univ-amu.fr

'Aix Marseille Université, Unité de Recherche en Maladies Infectieuses et Tropicales Emergentes (URMITE), UM63, CNRS 7278, IRD 198 (Dakar), Inserm 1095, Faculté de Médecine, 27 bd Jean Moulin, 13385 Marseille, Cedex 5, France

Full list of author information is available at the end of the article
}

vectors (after mosquitoes) of human disease and the most significant vectors of disease-causing pathogens in animals [2, 3]. Ticks can transmit a broad range of pathogens, including viruses, protozoa and bacteria [4]. Likewise, fleas are also able to transmit several agents of infectious diseases [5]. The transmission of these zoonotic agents to humans occurs mainly through their bites or inoculation of their infected feces into pruritic bite lesions [6-9]. Rickettsioses, bartonelloses and Q fever are vector-borne diseases that may be severe and that have a widespread geographical distribution. 
Rickettsia spp., the etiological agent of rickettsioses, are intracellular Gram-negative bacteria that represent an emergent global threat [10]. Ri. felis, an emerging pathogen, and $R i$. typhi, the agent of murine typhus (MT), are the main rickettsial pathogens associated with fleas [11], belonging to the spotted fever group (SFG) [12] and typhus group of rickettsiae, respectively [13]. Most of the SFG are transmitted by ticks [14] that are widely distributed in northern Africa $[15,16]$. In Algeria, 11 rickettsial pathogens have been detected in ticks, fleas, lice and humans, including Ri. conorii subspecies conorii, Ri. aeschlimannii, Ri. sibirica mongolitimonae, Ri. massiliae, Ri. slovaca, Ri. helvetica, Ri. africae, Ri. monacensis, Ri. felis, Ri. typhi and Ri. prowazekii [17].

Likewise, bartonelloses are diseases caused by fastidious, hemotropic bacteria from the genus Bartonella [18] which parasitize erythrocytes or epithelial cells across a range of mammalian hosts, including humans, rodents and chiroptera [19-21]. In Algeria, few investigations into the diversity of Bartonella spp. from animals and vectors have been conducted. Namely, B. vinsonii subsp. berkhoffii, B. clarridgeiae, and B. elizabethae were detected infecting domestic dogs [22, 23] and fleas collected from hedgehogs [24], B. henselae was isolated from stray cats [25] and $B$. rochalimae was detected in fleas collected from brown rats (Rattus norvegicus) [24].

In addition, Coxiella burnetii, the causative agent of $\mathrm{Q}$ fever, is a highly infectious zoonotic intracellular bacterium which can affect different species of wild and domestic mammals; it can also infect arthropods and birds [26]. In Algeria few human cases of $Q$ fever have been documented, with only two human cases reported in Oran [27].

The goal of this investigation was to assess the presence of emerging zoonotic bacteria in ectoparasites and tissues sampled from wild and domestic animals present in northeastern Algeria.

\section{Methods}

\section{Study areas}

The first part of the study was conducted in May 2012 in El Ghorra (Bougous, El Tarf) (36 39' 34' $\mathrm{N} 8^{\circ} 22^{\prime}$ $\left.10^{\prime \prime} \mathrm{E}\right)$ in the far northeast of Algeria. El Ghorra is a humid bioclimatic zone. It was the highest site in the study area, where the maximum altitude is $1202 \mathrm{~m}$ (Jebel El Ghorra). The relief of El Ghorra is characterized by a set of wooded mountains forming the "forest of El Ghorra". Its coverage includes $96 \%$ vegetation and $2 \%$ herbaceous layer, of which 500 ha are occupied by cork oak (Quercus suber) and 600 ha by canary oak, locally known as zeen oak (Quercus canariensis) [28].

The second part of this work was performed in July 2013, in Cheabat El Balout (Ouled Driss, Souk Ahras) in northeastern Algeria near El Tarf, $\left(36^{\circ} 22^{\prime} 01.30^{\prime \prime} \mathrm{N} 08^{\circ}\right.$
07' 27.48" E). This study area is mountainous and is located at $1000 \mathrm{~m}$ above sea level, representing an extension of the Telli Atlas. It has a semi-humid climate characterized by hot summers and cold, wet winters with a rainfall averaging $800 \mathrm{~mm}$ per year.

\section{Ectoparasite collection and tissue sampling}

The investigation in El Ghorra (Bougous, El Tarf) was conducted on domestic animals (cattle, sheep, goats and dogs). Ectoparasites were collected with the permission of the animals' owners. All arthropods were collected using blunted watchmakers forceps and immediately placed in tubes of $70 \%$ ethanol labeled with the identification number and the date of collection. A portion of the collected ectoparasites was used for the present study.

The field sampling in Cheabat El Balout (Ouled Driss, Souk Ahras) was conducted on wild mammals [two boars (Sus scrofa algira), two jackals (Canis aureus) one mongoose (Echinomon herpestis), ten bats (Chiroptera spp.), one porcupine (Hystrix cristata) and four hedgehogs (Atelerix algirus)]. Ectoparasites and tissues (spleens) were sampled. Hedgehogs were captured with the aid of flashlights during nightly walks through parts of the study regions near a poultry slaughterhouse. Hedgehogs were anesthetized using ketamine and released into their natural habitat after full recovery of ectoparasites.

Two boars, two jackals, one mongoose and one porcupine were found recently dead following road accidents and were also inspected for ectoparasites, and their spleens were sampled using adapted scalpels and stored in tubes containing $70 \%$ ethanol. Finally, we caught ten bats using hunting nets. The nets, identical to those used by ornithologists to capture and band birds, are very fine, and similar to a mesh-like fishing net. They are stretched between two poles, and placed at the entrance of the bat cave. Once detached from the nets, we searched for ectoparasites and took spleen samples.

All biological materials were forwarded thereafter to Marseille, France for morphological identification of ectoparasites at the species level using morphological criteria within standard taxonomic keys [29, 30]. Molecular analyses of ectoparasites and tissue samples were performed to detect Rickettsia spp., Bartonella spp., Coxiella burnetii and Borrelia spp.

\section{Ethical approval}

The study on hedgehogs was authorized by the local ethics committee and by national legislation (le journal officiel n 47 du 19 juillet 2006, http://www.iucnredlist.org/ apps/redlist/details/27926/0). Oral permission to place nets to trap bats in the study area was granted by the landowner, who placed his pets inside the cave in the rainy days. At the beginning of the study, the work on 
bats was programmed only on bats ectoparasites and when bats were recovered the next day, they were dead, that because we proceeded bats spleen also. In addition Algeria does not have ethical committee of bats. All experiments were done under the supervision of the Ministry of Health of Algeria.

\section{DNA extraction}

Prior to DNA extraction, a convenient sample was selected according to a good representation of species and hosts in El Ghorra (samples $<20$ were all processed while for samples $>20$ only 20 samples were processed). All collected ectoparasites and biological materials from Cheabat El Balout were used to extract their DNA.

Arthropods and spleens were rinsed twice in distilled water for $10 \mathrm{~min}$ and dried on sterile filter paper; handling was performed in a laminar flow biosafety cabinet. Ectoparasites and a portion of the spleen samples were individually crushed in sterile Eppendorf tubes. Total DNA was extracted in a final volume of $200 \mu \mathrm{l}$ from one half of each ectoparasite and a portion of the spleen using the QIAamp Tissue Kit (Qiagen, Hilden, Germany) by Qiagen-BioRobot EZ1, according to the manufacturer's instructions. Genomic DNA was stored at $-22{ }^{\circ} \mathrm{C}$ under sterile conditions.

\section{Detection of bacteria}

Once DNA had been extracted, it was used in qPCR template assays to detect Bartonella spp., Rickettsia spp., Coxiella burnetii and Borrelia spp. The final qPCR reaction mixture consisted of $5 \mu \mathrm{l}$ of DNA and $15 \mu \mathrm{l}$ of mix from the Takyon PCR Kit (Qiagen, Hilden, Germany) as described [31]. Negative controls were used in each qPCR and consisted of DNA extracted from uninfected ticks from our laboratory colony. Positive controls included DNA extracted from a dilution of cultured strains of B. elizabethae (detection of Bartonella spp.), Ri. montanensis (for the detection of Rickettsia spp.), Coxiella burnetii (for the detection of Coxiella burnetii) and Borrelia crocidurae (for the detection of Borrelia spp.). Results were deemed positive if the Cycle threshold $(\mathrm{Ct})$ value obtained by CFX96 was lower than 36 . All positive results were confirmed with a second $\mathrm{qPCR}$ system and/or sequence reaction.

\section{Detection of Bartonella spp.}

DNA samples were screened by qPCR targeting the ITS for the detection of Bartonella spp. [32]. The positive samples with ITS primers were then confirmed by standard PCR performed with Bartonella-specific primers of the intergenic spacer region between the $16 \mathrm{~S}$ and $23 \mathrm{~S}$ rRNA genes [33]. PCR amplification success was verified by migration in $2 \%$ Agarose gel, followed by purification using the NucleoFast 96 PCR plate (Machery-Nagel
EURL, France), as recommended by the manufacturer. The purified PCR products were sequenced using Urb1 and Urb2 primers and using BigDye version 1.1 Cycle Sequencing Ready Reaction Mix (Applied Biosystems, Foster City, CA). Data were collected with an ABI Prism 3130xl Genetic Analyzer capillary sequencer (ABI PRISM, PE Applied Biosystems, USA). Sequences were edited and assembled using Chromas Pro 1.34 (Technelysium Pty. Ltd., Tewantin, Australia). BLAST searches were performed to identify the obtained sequences.

\section{Detection of Rickettsia spp.}

Rickettsial DNA was detected using a Rickettsia genusspecific qPCR with a 25-bp probe targeting the partial sequence of the citrate synthase gene $($ glt $A)$ [34]. All tick samples identified as positive by qPCR were confirmed by a different standard PCR and sequencing for the fragments of OmpA gene [34]. DNA sequencing reactions were performed on highly positive samples $(\mathrm{Ct}<28)$. Tick samples with $\mathrm{Ct}>28$ were screened by qPCR specific to the species according to the sequencing result using $R i$. slovaca, Ri. massiliae or Ri. aeschlimannii qPCRs systems (Table 1), while flea samples testing positive with the RKND03 qPCR were directly tested with two qPCRs systems targeting the biotin synthase (bioB) and membrane phosphatase genes of Ri. felis [35]. Table 1 summarizes the probes and primers used to confirm and identify rickettsiae in samples.

\section{Detection of Borrelia spp.}

qPCR targeting the 16S rRNA gene was used, as described elsewhere [34], to screen DNA samples for all Borrelia spp.

\section{Detection of Coxiella burnetii}

Coxiella burnetii bacterial DNA was initially detected by qPCR with $C$. burnetii-specific primers and a probe designed to amplify the IS1111 gene [36]. qPCR with primers and a probe designed for the amplification of IS30a spacers were used to confirm C. burnetii-positive results [27].

\section{Results}

Sample collection and ectoparasites identification In El Ghorra, a total of 1549 ticks (Table 2) were collected, including eight species; 565 ticks were sampled from 123 cattle, 529 ticks from 250 sheep, 130 ticks were collected from 125 goats and 325 ticks were sampled from 50 dogs.

For the investigation on wild animals and their ectoparasites in Cheabat El Balout, 77 ticks, 136 fleas, 11 Nycteribiidae (Table 2) and 16 spleens were sampled (two spleens from boars, one from a mongoose, two from jackals, one from a porcupine and 10 from bats). 
Table 1 Target sequences, primers and probes used to confirm the detection of rickettsiae by qPCR

\begin{tabular}{|c|c|c|c|c|}
\hline $\begin{array}{l}\text { Quantitative real-time PCR } \\
\text { designation and specificity }\end{array}$ & $\begin{array}{l}\text { qPCR Sytem } \\
\text { used }\end{array}$ & Forward primer & Reverse primer & Probe \\
\hline Rickettsia felis & $\begin{array}{l}\text { Biotin } \\
\text { synthase }\end{array}$ & $\begin{array}{l}\text { ATG-TTC-GGG-CTTCCG- } \\
\text { GTA-TG }\end{array}$ & $\begin{array}{l}\text { CCG-ATT-CAG-CAGGTT- } \\
\text { CTT-CAA }\end{array}$ & $\begin{array}{l}\text { 6-FAM- GCT-GCG-GCGGTA-TTT-TAG-GAA } \\
\text {-TGGG-TAMRA }\end{array}$ \\
\hline Rickettsia aeschlimannii & Scal & $\begin{array}{l}\text { AAGCGGCACTTTAGGTA } \\
\text { AAGAAA }\end{array}$ & CATGCTCTGCAAATGAACCA & $\begin{array}{l}\text { 6FAM-TGGGGAAATATGCCGTATACGCAAGC } \\
\text {-TAMRA }\end{array}$ \\
\hline Rickettsia massiliae & R.mass_9666 & CCAACCTITGTTGTTGCAC & TTGGATCAGTGTGACGGACT & $\begin{array}{l}\text { 6FAM-CACGTGCTGCTTATACCAGCAAACA } \\
\text {-TAMRA }\end{array}$ \\
\hline Rickettsia slovaca & R.slov & GCAACGGTTITTGGTATCGT & AATCGAATGCACCACCACTT & 6FAM- TCCCGTCCCAGCCATTCGTC -TAMRA \\
\hline
\end{tabular}

\section{Detection of Bartonella spp.}

All the selected 191 ticks of El Ghorra (Table 2) tested negative for Bartonella spp. However, out of all ticks, fleas, Nycteribiidae and spleen portions, 26 samples collected from bats were positive, including 12/19 (63.2\%) of I. vespertilionis ticks, 8/11 (72.7\%) Nycteribiidae flies and 6/10 (60\%) spleens. The results showed that all sequences of Bartonella spp. detected in ectoparasites and bat spleens were similar to the sequence of $B$. tamiae (100\% similarity with the Bartonella tamiae strain Th339 16S-23S ribosomal RNA intergenic spacer, partial sequence, GenBank no EF605284.1, 451/451 bp).

\section{Detection of Rickettsia spp.}

In El Ghorra, 29/191 (15.2 \%) of ticks tested positive for Rickettsia spp. by qPCR. These included 15/29 (51.7\%) R. sanguineus sensu lato, 2/29 (6.9 \%) R. bursa, 6/29 (20.7 \%) Hy. scupense and 6/29 (20.7 \%) Hy. a. excavatum. Concerning the $15 R$. sanguineus sensu lato that were Rickettsia spp.-positive, 3 were collected from cattle, 11 from sheep and 1 from dogs. The two R. bursa were sampled from cattleas well as all six Hy. scupense. Finally, the $6 \mathrm{Hy}$. a. excavatum were sampled from goats. DNA sequence analyses of the PCR products targeting OmpA on the $R$. sanguineus sensu lato and $R$. bursa ticks showed $100 \%$ similarity with Rickettsia massiliae (GenBank accession no. U43793.1), regardless of the host's tick type. In addition, the sequencing of the $O m p A$ gene fragment from the positive Hy. scupense and $H y$. a. excavatum showed $100 \%$ similarity with Rickettsia aeschlimannii strain EgyRickHimp-El-Arish17 outer membrane protein A $(O m p A)$ gene, partial cds (GenBank accession no. HQ335158.1, 633/633 bp).

In Cheabat el Balout, the RKND03 qPCR system was used to test the 77 ticks, 136 fleas, 11 Nycteribiidae flies and 16 spleens sampled from wild animals. Overall, we detected DNA from Rickettsia spp. in three ticks from boars (two D. marginatus and one Hae. punctata), in 80 $A$. erinacei and two C. felis fleas from hedgehogs. The DNA sequence of the two rickettsia-positive D. marginatus and Hae. punctata showed $100 \%$ similarity with Rickettsia slovaca strain WB2/Dm Pavullo outer membrane protein A $(O m p A)$ gene, partial cds GenBank accession no. HM161787.1, 633/633 bp). Concerning the $80 \mathrm{~A}$. erinacei and $2 \mathrm{C}$. felis of hedgehogs positive for Rickettsia spp, all 82 fleas were positive for $R i$. felis (Table 2).

\section{Detection of Coxiella burnetii}

In El Ghorra, all the 191 screened ticks were negative, however in Cheabat el Balout, we detected DNA from $C$. burnetii in three I. vespertilionis of bats. We confirmed the result using the second qPCR system (Table 2).

\section{Detection of Borrelia spp.}

All tested samples were negative for Borrelia spp. using the $16 \mathrm{~S}$ qPCR system from the Borrelia genus.

\section{Discussion}

This investigation reports the first direct evidence of DNA from B. tamiae in I. vespertilionis, Nycteribiidae and bat spleens in Algeria. The association between the DNA from Ri. slovaca and Hae. punctata from boars and also between Ri. massiliae and R. bursa from cattle are reported for the first time in Algeria. Other rickettsiae were detected in this field as previously detected in Algeria, namely Ri. massiliae in $R$. sanguineus sensu lato, Ri. aeschlimannii in Hyalomma spp. ticks and Ri. felis in A. erinacei and in C. felis fleas. Using molecular tools $C$. burnetii, the agent of $\mathrm{Q}$ fever, was also detected in I. vespertilionis ticks of bat. Since ticks were removed from animals that in some cases could have been bacteremic, the ticks can be vectors for some pathogens but also only carriers in other cases. As a consequence, we cannot consider the presence of bacteria in the ectoparasite as proof of vector competence.

Bartonella-associated illnesses occur worldwide, and they encompass a broad clinical spectrum, including fever, skin lesions, endocarditis, lymphadenopathy, and abnormalities of the central nervous system, eye, liver and bone tissues [37]. Bartonella tamiae is a newly described bacterial species, initially isolated from the blood of three hospitalized patients in Thailand [33]. These patients presented with headache, myalgia, anemia, and mild liver function abnormalities [38]. This 
Table 2 Detection of Rickettsiae, Bartonella spp., and Coxiella burnetii in arthropods

\begin{tabular}{|c|c|c|c|c|c|c|c|}
\hline $\begin{array}{l}\text { Ectoparasite } \\
\text { species }\end{array}$ & Localization & Animal (N) & $\begin{array}{l}\text { No. of ectoparasites collected } \\
\text { ( } \mathrm{m}=\text { male, } \mathrm{f}=\text { female) }\end{array}$ & $\begin{array}{l}\text { No. of ectoparasites } \\
\text { tested by } \mathrm{QPCR} \\
\text { ( } \mathrm{m}=\text { male, } \mathrm{f}=\text { female) }\end{array}$ & Rickettsia spp & $\begin{array}{l}\text { Bartonella } \\
\text { spp }\end{array}$ & $\begin{array}{l}\text { Coxiella } \\
\text { burnetii }\end{array}$ \\
\hline \multirow[t]{8}{*}{$\begin{array}{l}\text { Rhipicephalus } \\
\text { sanguineus }\end{array}$} & \multirow[t]{4}{*}{$\begin{array}{l}\text { El Ghorra, } \\
\text { El Tarf. }\end{array}$} & Cattle (123) & $316(104$ m, 212f) & $20(10 \mathrm{~m}, 10 \mathrm{f})$ & $\begin{array}{l}\text { 3/20 (1 m, 2f) } \\
\text { Ri. massiliae }\end{array}$ & - & - \\
\hline & & Sheep (250) & 454 (217 m, 237f) & $20(10 \mathrm{~m}, 10 \mathrm{f})$ & $\begin{array}{l}\text { 11/20 (9 m, 2f) } \\
\text { Ri. massiliae }\end{array}$ & - & - \\
\hline & & Goats (128) & $104(55$ m, 49f) & 20 (10 m, 10f) & - & - & - \\
\hline & & Dogs (50) & $323(222 \mathrm{~m}, 101 \mathrm{f})$ & $20(10 \mathrm{~m}, 10 \mathrm{f})$ & $\begin{array}{l}\text { 1/20 (1 m) } \\
\text { Ri. massiliae }\end{array}$ & - & - \\
\hline & \multirow{4}{*}{$\begin{array}{l}\text { Cheabat El } \\
\text { Balout, Souk } \\
\text { Ahras }\end{array}$} & Boars (2) & $9(5 m, 4 f)$ & $9(5 \mathrm{~m}, 4 f)$ & $\begin{array}{l}8 / 9(5 \mathrm{~m}, 3 f) \\
\text { Ri. massiliae }\end{array}$ & - & - \\
\hline & & $\begin{array}{l}\text { Mangoose } \\
\text { (1) }\end{array}$ & $2(1 \mathrm{~m}, 1 \mathrm{f})$ & $2(1 \mathrm{~m}, 1 \mathrm{f})$ & $\begin{array}{l}2 / 2(1 \mathrm{~m}, 1 \mathrm{f}) \\
\text { Ri. massiliae }\end{array}$ & - & - \\
\hline & & Jackals (2) & $23(15 \mathrm{~m}, 8 \mathrm{f})$ & $23(15 \mathrm{~m}, 8 f)$ & $\begin{array}{l}\text { 13/23(8 m, 5f) } \\
\text { Ri. massiliae }\end{array}$ & - & - \\
\hline & & $\begin{array}{l}\text { Hedgehogs } \\
\text { (4) }\end{array}$ & $10(2 \mathrm{~m}, 8 f)$ & $10(2 \mathrm{~m}, 8 f)$ & - & - & - \\
\hline \multirow[t]{3}{*}{$\begin{array}{l}\text { Rhipicephalus } \\
\text { bursa }\end{array}$} & \multirow[t]{3}{*}{$\begin{array}{l}\text { El Ghorra, } \\
\text { El Tarf. }\end{array}$} & Cattle (123) & $50(39 \mathrm{~m}, 11 \mathrm{f})$ & $20(10 \mathrm{~m}, 10 \mathrm{f})$ & $\begin{array}{l}\text { 2/20 (2f) } \\
\text { Ri. massiliae }\end{array}$ & - & - \\
\hline & & Sheep (250) & 72 (37 m, 35f) & $20(10 \mathrm{~m}, 10 \mathrm{f})$ & - & - & - \\
\hline & & Goats (128) & 19 (19 m) & $19(19 \mathrm{~m})$ & - & - & - \\
\hline \multirow{2}{*}{$\begin{array}{l}\text { Hyalomma } \\
\text { lusitanicum }\end{array}$} & \multirow{2}{*}{$\begin{array}{l}\text { El Ghorra, } \\
\text { El Tarf. }\end{array}$} & Sheep (250) & $1(1 \mathrm{~m})$ & $1(1 \mathrm{~m})$ & - & - & - \\
\hline & & Goats (128) & $3(2 \mathrm{~m}, 1 \mathrm{f})$ & $3(2 \mathrm{~m}, 1 \mathrm{f})$ & - & - & - \\
\hline \multirow[t]{2}{*}{$\begin{array}{l}\text { Hyalomma } \\
\text { scupense }\end{array}$} & \multirow[t]{2}{*}{$\begin{array}{l}\text { El Ghorra, } \\
\text { El Tarf. }\end{array}$} & Cattle (123) & $94(41 \mathrm{~m}, 53 \mathrm{f})$ & $20(10 \mathrm{~m}, 10 f)$ & $\begin{array}{l}6 / 20(2 \mathrm{~m}, 4 \mathrm{f}) \\
\text { Ri. aeschlimannii }\end{array}$ & - & - \\
\hline & & Sheep (250) & 1 (1f) & $1(1 \mathrm{f})$ & - & - & - \\
\hline $\begin{array}{l}\text { Hyalomma } \\
\text { anatolicum } \\
\text { excavatum }\end{array}$ & $\begin{array}{l}\text { El Ghorra, } \\
\text { El Tarf. }\end{array}$ & Cattle (123) & 105 (54 m, 51f) & $20(10 \mathrm{~m}, 10 \mathrm{f})$ & $\begin{array}{l}6 / 20(4 \mathrm{~m}, 2 \mathrm{f}) \\
\text { Ri. aeschlimannii }\end{array}$ & - & - \\
\hline $\begin{array}{l}\text { Hyalomma } \\
\text { marginatum }\end{array}$ & $\begin{array}{l}\text { El Ghorra, } \\
\text { El Tarf. }\end{array}$ & Goats (128) & $4(4 f)$ & $4(4 f)$ & - & - & - \\
\hline \multirow[t]{2}{*}{ Ixodes ricinus } & $\begin{array}{l}\text { El Ghorra, } \\
\text { El Tarf. }\end{array}$ & Sheep (250) & $1(1 \mathrm{~m})$ & $1(1 \mathrm{~m})$ & - & - & - \\
\hline & $\begin{array}{l}\text { Cheabat } \\
\text { El Balout, } \\
\text { Souk Ahras }\end{array}$ & $\begin{array}{l}\text { Mongoose } \\
\text { (1) }\end{array}$ & $1(1 \mathrm{~m})$ & $1(1 \mathrm{~m})$ & - & - & - \\
\hline \multirow[t]{2}{*}{$\begin{array}{l}\text { Ixodes } \\
\text { hexagonus }\end{array}$} & $\begin{array}{l}\text { El Ghorra, } \\
\text { El Tarf. }\end{array}$ & Dogs (50) & $2(2 f)$ & $2(2 f)$ & - & - & - \\
\hline & $\begin{array}{l}\text { Cheabat El } \\
\text { Balout, Souk } \\
\text { Ahras }\end{array}$ & $\begin{array}{l}\text { Hedgehogs } \\
\text { (4) }\end{array}$ & $9(1 \mathrm{~m}, 8 \mathrm{f})$ & $9(1 \mathrm{~m}, 8 \mathrm{f})$ & - & - & - \\
\hline $\begin{array}{l}\text { Dermacentor } \\
\text { marginatus }\end{array}$ & $\begin{array}{l}\text { Cheabat El } \\
\text { Balout, Souk } \\
\text { Ahras }\end{array}$ & Boars (2) & $3(3 f)$ & $3(3 f)$ & $\begin{array}{l}2 / 3(2 f) \\
\text { Ri. slovaca }\end{array}$ & - & - \\
\hline $\begin{array}{l}\text { Haemaphysalis } \\
\text { punctata }\end{array}$ & $\begin{array}{l}\text { Cheabat El } \\
\text { Balout, Souk } \\
\text { Ahras }\end{array}$ & Boars (2) & $1(1 \mathrm{f})$ & $1(1 \mathrm{f})$ & $\begin{array}{l}\text { 1/1 (1f) } \\
\text { Ri. slovaca }\end{array}$ & - & - \\
\hline $\begin{array}{l}\text { Ixodes } \\
\text { vespertilionis }\end{array}$ & $\begin{array}{l}\text { Cheabat El } \\
\text { Balout, Souk } \\
\text { Ahras }\end{array}$ & Bats (10) & 19 (2f, 17 nymphs) & 19 (2f, 17 nymphs) & - & $\begin{array}{l}\text { 12/19 (1f, } 11 \\
\text { nymphs) } B . \\
\text { tamiae }\end{array}$ & $\begin{array}{l}3 / 19 \\
(2 f, 1 \text { nymph })\end{array}$ \\
\hline \multirow[t]{2}{*}{$\begin{array}{l}\text { Ischnopsyllus } \\
\text { intermedius }\end{array}$} & $\begin{array}{l}\text { Cheabat El } \\
\text { Balout, Souk } \\
\text { Ahras }\end{array}$ & Bats (10) & $3(3 f)$ & $3(3 f)$ & - & - & - \\
\hline & & & $2(2 f)$ & $2(2 f)$ & 2/2 (2f) Ri. felis & - & - \\
\hline
\end{tabular}


Table 2 Detection of Rickettsiae, Bartonella spp., and Coxiella burnetii in arthropods (Continued)

\begin{tabular}{|c|c|c|c|c|c|c|c|}
\hline $\begin{array}{l}\text { Ctencephalides } \\
\text { felis }\end{array}$ & $\begin{array}{l}\text { Cheabat El } \\
\text { Balout, Souk } \\
\text { Ahras }\end{array}$ & $\begin{array}{l}\text { Hedgehogs } \\
\text { (4) }\end{array}$ & & & & & \\
\hline $\begin{array}{l}\text { Pariodontis } \\
\text { riggenbachi }\end{array}$ & $\begin{array}{l}\text { Cheabat El } \\
\text { Balout, Souk } \\
\text { Ahras }\end{array}$ & $\begin{array}{l}\text { Porcupine } \\
\text { (1) }\end{array}$ & $21(3 \mathrm{~m}, 18 f)$ & $21(3 \mathrm{~m}, 18 \mathrm{f})$ & - & - & - \\
\hline Nycteribiidae & $\begin{array}{l}\text { Cheabat El } \\
\text { Balout, Souk } \\
\text { Ahras }\end{array}$ & Bats (10) & $11(5 \mathrm{~m}, 6 \mathrm{f})$ & $11(5 \mathrm{~m}, 6 \mathrm{f})$ & - & $\begin{array}{l}8 / 11 B . \\
\text { tamiae }\end{array}$ & - \\
\hline $\begin{array}{l}\text { Archaeopsylla } \\
\text { erinacei }\end{array}$ & $\begin{array}{l}\text { Cheabat El } \\
\text { Balout, Souk } \\
\text { Ahras }\end{array}$ & $\begin{array}{l}\text { Hedgehogs } \\
\text { (4) }\end{array}$ & 110 (39 m, 71f) & $110(39 \mathrm{~m}, 71 \mathrm{f})$ & $\begin{array}{l}\text { 80/110 (19 m, } \\
\text { 61f) Ri. felis }\end{array}$ & - & - \\
\hline
\end{tabular}

novel Bartonella species has been newly recognized as a pathogen [33, 39]. Throughout our investigation, $B$. tamiae was detected for the first time in Algeria, and in ticks, Nycteribiidae and bat spleens. Bats are the second species group of mammals after rodents confirmed to carry Bartonella spp. [40]. Renewed interest in Bartonella research in mammals has confirmed the presence of Bartonella spp. in bats in Guatemala, Kenya [41] and the United Kingdom [42].

C. burnetii was also detected in this study; this pathogenic agent of $\mathrm{Q}$ fever is associated with many manifestations [26, 43]. Q fever is typically an acute febrile illness with nonspecific clinical signs in humans, but isolated fever, hepatitis and/or atypical pneumonia are the most commonly described manifestations. A small proportion of infected people develop life-threatening valvular endocarditis [26, 43]. Q fever has been described worldwide in outbreaks involving sheep, goats, cats, dogs and wild animals, while reservoirs are extensive but only partially known and include mammals, birds, and arthropods, mainly ticks [44]. In Algeria, few human cases have been reported, including one in 2005 , where two patients were found to be seropositive for $C$. burnetii (one was confirmed positive by nested PCR) [45]. In 2012, through 268 qPCR-tested samples from Oran, Western Algeria, only one patient was positive for C. burnetii [27].

B. tamiae and C. burnetii were detected in I. vespertilionis. This tick species parasitizes bats specifically [46, 47]. Humans can also act as accidental hosts [48]. I. vespertilionis represents little interest for human health because it is restricted to the darkest part of bat caves [49]. In literature, no evidence was found to prove that this species can transmit pathogens to humans or other animals [49]. We detected Ri. slovaca in ticks from boars, namely in Hae. punctata and D. marginatus. Our detection of Ri. slovaca in Hae. punctata ticks may be due to co-feeding with infected $D$. marginatus, which is a recognized vector and reservoir of the bacteria. Literature reported also the possibility of transmission to other tick species by feeding on bacteremic animals, as is the case of $R i$. slovaca [50]. Ri. slovaca is associated with a syndrome characterized by scalp eschar and neck lymphadenopathy following tick bites [51]. In Algeria, Ri. slovaca was previously detected in $D$. marginatus ticks collected from vegetation in the Blida region, in 2012 [52].

In Algeria, Ri. massiliae was detected in $R$. turanicus, in 2006 [53]. Our results confirm the presence of $R i$. massiliae in Algerian ticks, where we detected it in $R$. sanguineus sensu lato from cattle, sheep, dogs and boars. Using qPCR, it was also detected in $R$. bursa from cattle. These SFG rickettsiae were described in 1992, and then subsequently detected in other Rhipicephalus spp., including R. bursa in European countries [51].

Our results indicate the presence of $R i$. aeschlimannii in Hy. a. excavatum and Hy. scupense ticks from cattle in the far northeast of Algeria. Ri. aeschlimannii is an emerging pathogen that causes symptoms similar to those of Mediterranean spotted fever [51]. It has been associated with ticks, particularly with $H y$. marginatum and Hy. rufipes ticks, in southern Europe and Africa [51].

In Algeria, Ri. aeschlimannii was previously detected in Hy. dromedarii and Hy. rufipes from camels from southern Algeria [54] and Hy. aegyptium ticks from tortoises trapped near Algiers [55]. Our results confirm the presence of $R i$. aeschlimannii in Algeria but also complete the geographical distribution of this pathogen from the south and center to the far northeast.

Finally, we detected DNA from Ri. felis in hedgehog fleas (Ct. felis and A. erinacei). Ri. felis is an emergent agent of infectious diseases in humans, and this SFG agent is known to be maintained in cat fleas (Ct. felis) $[56,57]$. To date, 12 flea species, eight tick species and three mite species have been found to be infected with Ri. felis [57]. These rickettsiae have also recently been detected in several mosquito species in sub-Saharan Africa [31, 58, 59]. Clinical features may include fever, fatigue, headache, generalized maculopapular rash and inoculation eschar(s) [57]. It is known to be a frequent 
agent of fever of unknown origin [60]. In Algeria Ri. felis was previously detected in $A$. erinacei fleas of hedgehogs of M'sila and Bordj-Bou-Arreridj, Algeria [61, 62]. It was also detected in Ct. canis [60]. Here, we report for the first time the presence of Ri. felis in Ct. felis fleas from Algeria.

\section{Conclusion}

For the first time in Algeria, we detected B. tamiae, Coxiella burnetii and rickettsiae (Ri. slovaca, Ri. massiliae, Ri. aeschlimannii and Ri. felis) in two regions of the far northeast of Algeria. We expanded knowledge of the repertoire of ticks and flea-borne bacteria present in ectoparasites and/or tissues of domestic and wild animals in Algeria. Our findings will help human and veterinary clinicians to enlarge the spectrum of pathogens to consider in differential diagnosis. Future studies on rickettsioses, bartonelloses and other vector-borne diseases should be performed to assess their epidemiological and clinical relevance in Algeria, to estimate the actual prevalence and to allow the establishment of anti-vector control plans.

\section{Competing interests}

The authors declare that they have no competing interests.

\section{Authors' contributions}

$\mathrm{HL}$ contributed to arthropod collections (first part), performed DNA extractions, QPCRs, sequencing and created the first draft of the paper. AA contributed to arthropod collections (second part) and preparation of the manuscript. IB analyzed the data, coordinated the study and identified the arthropods. ABES contributed to the preparation of the manuscript. ABEN contributed to creating, designing and coordinating the study. DR contributed reagents/materials/analysis tools and analyzed the data. PP created, designed and coordinated the experiment. All authors read and approved the final manuscript.

\section{Acknowledgements}

This work was carried out thanks to the support of the $A^{*}$ MIDEX project ( $n^{\circ}$ ANR-11-IDEX-0001-02) funded by the French Government's "Investissements d'Avenir" program, managed by the French National Research Agency (ANR).

\begin{abstract}
Author details
'Aix Marseille Université, Unité de Recherche en Maladies Infectieuses et Tropicales Emergentes (URMITE), UM63, CNRS 7278, IRD 198 (Dakar), Inserm 1095, Faculté de Médecine, 27 bd Jean Moulin, 13385 Marseille, Cedex 5, France. ${ }^{2} E$ Ecole Nationale Supérieure Vétérinaire d'Alger. El Aliya Alger, Algiers 16000, Algeria. ${ }^{3}$ Département des Sciences Vétérinaires, Université Cherif Messaadia, Souk Ahras 41000, Algeria. ${ }^{4}$ Département des Sciences Vétérinaires, Université Chadli Bendjdid, El Tarf 36000, Algeria. ${ }^{5}$ Laboratoire d'Ecologie et Environnement: Interaction, Génome, Université de Bab Ezzouar, Bab Ezzouar 16000, Algeria.
\end{abstract}

Received: 25 June 2015 Accepted: 15 January 2016

Published online: 20 January 2016

\section{References}

1. Parola P, Paddock CD, Raoult D. Tick-borne rickettsioses around the world: emerging diseases challenging old concepts. Clin Microbiol Rev. 2005;18:719-56.

2. Parola P, Raoult D. Ticks and tickborne bacterial diseases in humans: an emerging infectious threat. Clin Infect Dis. 2001;32:897-928.

3. Mediannikov O, Fenollar F. Looking in ticks for human bacterial pathogens. Microb Pathog. 2014;77:142-8.

4. Baneth G. Tick-borne infections of animals and humans: a common ground. Int J Parasitol. 2014;44:591-6.
5. Bitam I, Dittmar K, Parola P, Whiting MF, Raoult D. Fleas and flea-borne diseases. Int J Infect Dis. 2010;14:e667-76.

6. Parola P, Davoust B, Raoult D. Tick- and flea-borne rickettsial emerging zoonoses. Vet Res. 2005;36:469-92.

7. Eisen RJ, Gage KL. Transmission of flea-borne zoonotic agents. Annu Rev Entomol. 2012:57:61-82

8. Knobel DL, Maina AN, Cutler SJ, Ogola E, Feikin DR, Junghae M, et al. Coxiella burnetii in humans, domestic ruminants, and ticks in rural western Kenya. Am J Trop Med Hyg. 2013;88:513-8.

9. Gil H, Escudero R, Pons I, Rodriguez-Vargas M, Garcia-Esteban C, RodriguezMoreno I, et al. Distribution of Bartonella henselae variants in patients, reservoir hosts and vectors in Spain. PLoS One. 2013;8:e68248.

10. Parola P, Raoult D. Tropical rickettsioses. Clin Dermatol. 2006;24:191-200.

11. Znazen A, Khrouf F, Elleuch N, Lahiani D, Marrekchi C, M'Ghirbi Y, et al. Multispacer typing of Rickettsia isolates from humans and ticks in Tunisia revealing new genotypes. Parasit Vectors. 2013;6:367.

12. Merhej V, El KK, Raoult D. Whole genome-based phylogenetic analysis of Rickettsiae. Clin Microbiol Infect. 2009;15 Suppl 2:336-7.

13. Nogueras MM, Pons I, Ortuno A, Miret J, Pla J, Castella J, et al. Molecular detection of Rickettsia typhi in cats and fleas. PLoS One. 2013;8:e71386.

14. Bitam I. Vectors of rickettsiae in Africa. Ticks Tick Borne Dis. 2012;3:382-6.

15. Mouffok N, Parola P, Lepidi H, Raoult D. Mediterranean spotted fever in Algeria-new trends. Int I Infect Dis. 2009;13:227-35.

16. Abdel-Shafy S, Allam NA, Mediannikov O, Parola P, Raoult D. Molecular detection of spotted fever group rickettsiae associated with ixodid ticks in Egypt. Vector Borne Zoonotic Dis. 2012;12:346-59.

17. Kernif T, Socolovschi C, Bitam I, Raoult D, Parola P. Vector-borne rickettsioses in North Africa. Infect Dis Clin North Am. 2012:26:455-78.

18. Chomel BB, Boulouis HJ, Breitschwerdt EB, Kasten RW, Vayssier-Taussat M, Birtles RJ, et al. Ecological fitness and strategies of adaptation of Bartonella species to their hosts and vectors. Vet Res. 2009;40:29.

19. Mogollon-Pasapera E, Otvos Jr L, Giordano A, Cassone M. Bartonella: emerging pathogen or emerging awareness? Int J Infect Dis. 2009;13:3-8.

20. Chomel BB, Kasten RW. Bartonellosis, an increasingly recognized zoonosis. J Appl Microbiol. 2010;109:743-50.

21. Harms A, Dehio C. Intruders below the radar: molecular pathogenesis of Bartonella spp. Clin Microbiol Rev. 2012;25:42-78.

22. Azzag N, Petit E, Gandoin C, Bouillin C, Ghalmi F, Haddad N, et al. Prevalence of select vector-borne pathogens in stray and client-owned dogs from Algiers. Comp Immunol Microbiol Infect Dis. 2015:38:1-7.

23. Kernif T, Aissi M, Doumandji SE, Chomel BB, Raoult D, Bitam I. Molecular evidence of Bartonella infection in domestic dogs from Algeria, North Africa, by polymerase chain reaction (PCR). Am J Trop Med Hyg. 2010;83:298-300.

24. Bitam I, Rolain JM, Nicolas V, Tsai YL, Parola P, Gundi VA, et al. A multi-gene analysis of diversity of Bartonella detected in fleas from Algeria. Comp Immunol Microbiol Infect Dis. 2012:35:71-6.

25. Azzag N, Haddad N, Durand B, Petit E, Ammouche A, Chomel B, et al. Population structure of Bartonella henselae in Algerian urban stray cats. PLoS One. 2012;7:e43621.

26. Maurin M, Raoult D. Q fever. Clin Microbiol Rev. 1999:12:518-53.

27. Angelakis E, Mediannikov O, Socolovschi C, Mouffok N, Bassene H, Tall A, et al. Coxiella burnetii-positive PCR in febrile patients in rural and urban Africa. Int J Infect Dis. 2014;28:107-10.

28. Sobhi Z, Allal-Benfekih L, Petit D. Biodiversité acaridienne des zonnes humides et des écosystemes forestiers (de Quercus suber et de Q. canariensis): effets du climat et de la végétation. Bull Soc Zool Fr. 2013;138:229-50.

29. Bouattour A. Dichotomous identification keys of ticks (Acari: Ixodidae), livestock parasites in North Africa. Arch Inst Pasteur Tunis. 2002:79:43-50.

30. Beaucournu J-C, Launay H. Les puces (Siphonaptera) de France et du Bassin méditerranéen occidental. 1990.

31. Socolovschi C, Pages F, Raoult D. Rickettsia felis in Aedes albopictus mosquitoes, Libreville, Gabon. Emerg Infect Dis. 2012;18:1687-9.

32. Varagnol M, Parola P, Jouan R, Beaucournu JC, Rolain JM, Raoult D. First detection of Rickettsia felis and Bartonella clarridgeiae in fleas from Laos. Clin Microbiol Infect. 2009:15 Suppl 2:334-5.

33. Kosoy M, Morway C, Sheff KW, Bai Y, Colborn J, Chalcraft L, et al. Bartonella tamiae sp. nov., a newly recognized pathogen isolated from three human patients from Thailand. J Clin Microbiol. 2008;46:772-5.

34. Socolovschi C, Kernif T, Raoult D, Parola P. Borrelia, Rickettsia, and Ehrlichia species in bat ticks, France, 2010. Emerg Infect Dis. 2012;18:1966-75. 
35. Leulmi H, Socolovschi C, Laudisoit A, Houemenou G, Davoust B, Bitam I, et al. Detection of Rickettsia felis, Rickettsia typhi, Bartonella Species and Yersinia pestis in Fleas (Siphonaptera) from Africa. PLoS Negl Trop Dis. 2014;8:e3152.

36. Mediannikov O, Fenollar F, Socolovschi C, Diatta G, Bassene H, Molez JF, et al. Coxiella burnetii in humans and ticks in rural Senegal. PLoS Negl Trop Dis. 2010;4:e654.

37. Jacomo V, Kelly PJ, Raoult D. Natural history of Bartonella infections (an exception to Koch's postulate). Clin Diagn Lab Immunol. 2002;9:8-18.

38. Colton L, Zeidner N, Lynch T, Kosoy MY. Human isolates of Bartonella tamiae induce pathology in experimentally inoculated immunocompetent mice. BMC Infect Dis. 2010;10:229.

39. Kabeya H, Colborn JM, Bai Y, Lerdthusnee K, Richardson JH, Maruyama S, et al. Detection of Bartonella tamiae DNA in ectoparasites from rodents in Thailand and their sequence similarity with bacterial cultures from Thai patients. Vector Borne Zoonotic Dis. 2010;10:429-34.

40. Concannon R, Wynn-Owen K, Simpson VR, Birtles RJ. Molecular characterization of haemoparasites infecting bats (Microchiroptera) in Cornwall, UK. Parasitology. 2005:131:489-96.

41. Kosoy M, Bai Y, Lynch T, Kuzmin IV, Niezgoda M, Franka R, et al. Bartonella spp. in bats, Kenya. Emerg Infect Dis. 2010;16:1875-81.

42. Bai Y, Kosoy M, Recuenco S, Alvarez D, Moran D, Turmelle A, et al. Bartonella spp. in Bats, Guatemala. Emerg Infect Dis. 2011;17:1269-72.

43. Kazar J. Coxiella burnetii infection. Ann N Y Acad Sci. 2005;1063:105-14.

44. Angelakis E, Raoult D. Q Fever. Vet Microbiol. 2010;140:297-309.

45. Benslimani A, Fenollar F, Lepidi H, Raoult D. Bacterial zoonoses and infective endocarditis, Algeria. Emerg Infect Dis. 2005;11:216-24.

46. Arthur DR. The Ixodes ticks of Chiroptera (Ixodoidea, Ixodidae). J Parasitol. 1956;42:180-96

47. Hornok S, Estrada-Pena A, Kontschan J, Plantard O, Kunz B, Mihalca AD, et al. High degree of mitochondrial gene heterogeneity in the bat tick species Ixodes vespertilionis, I. ariadnae and I. simplex from Eurasia. Parasit Vectors. 2015;8:457.

48. Piksa K, Gorz A, Nowak-Chmura M, Siuda K. The patterns of seasonal activity of Ixodes vespertilionis (Acari: Ixodidae) on Rhinolophus hipposideros in nursery colonies. Ticks Tick Borne Dis. 2014;5:69-74

49. Obsomer V, Wirtgen M, Linden A, Claerebout E, Heyman P, Heylen D, et al. Spatial disaggregation of tick occurrence and ecology at a local scale as a preliminary step for spatial surveillance of tick-borne diseases: general framework and health implications in Belgium. Parasit Vectors. 2013;6:190.

50. Parola P, Cornet JP, Sanogo YO, Miller RS, Thien HV, Gonzalez JP, et al. Detection of Ehrlichia spp., Anaplasma spp., Rickettsia spp., and other eubacteria in ticks from the Thai-Myanmar border and Vietnam. J Clin Microbiol. 2003:41:1600-8

51. Parola P, Paddock CD, Socolovschi C, Labruna MB, Mediannikov O, Kernif T, et al. Update on tick-borne rickettsioses around the world: a geographic approach. Clin Microbiol Rev. 2013;26:657-702.

52. Kernif T, Messaoudene D, Ouahioune S, Parola P, Raoult D, Bitam I. Spotted fever group rickettsiae identified in Dermacentor marginatus and Ixodes ricinus ticks in Algeria. Ticks Tick Borne Dis. 2012;3:380-1.

53. Bitam I, Parola P, Matsumoto K, Rolain JM, Baziz B, Boubidi SC, et al. First molecular detection of $R$. conorii, R. aeschlimannii, and R. massiliae in ticks from Algeria. Ann N Y Acad Sci. 2006;1078:368-72.

54. Djerbouh A, Kernif T, Beneldjouzi A, Socolovschi C, Kechemir N, Parola P, et al. The first molecular detection of Rickettsia aeschlimannii in the ticks of camels from southern Algeria. Ticks Tick Borne Dis. 2012;3:374-6.

55. Bitam I, Kernif T, Harrat Z, Parola P, Raoult D. First detection of Rickettsia aeschlimannii in Hyalomma aegyptium from Algeria. Clin Microbiol Infect. 2009;15 Suppl 2:253-4

56. La Scola B, Meconi S, Fenollar F, Rolain JM, Roux V, Raoult D. Emended description of Rickettsia felis (Bouyer et al. 2001), a temperature-dependent cultured bacterium. Int J Syst Evol Microbiol. 2001;2002(52):2035-41.

57. Parola P. Rickettsia felis: from a rare disease in the USA to a common cause of fever in sub-Saharan Africa. Clin Microbiol Infect. 2011;17:996-1000.

58. Keita AK, Socolovschi C, Ahuka-Mundeke S, Ratmanov P, Butel C, Ayouba A, et al. Molecular evidence for the presence of Rickettsia felis in the feces of wild-living African apes. PLoS One. 2013;8:e54679.

59. Mediannikov O, Socolovschi C, Edouard S, Fenollar F, Mouffok N, Bassene H, et al. Common epidemiology of Rickettsia felis infection and malaria, Africa. Emerg Infect Dis. 2013;19:1775-83.
60. Bitam I, Baziz B, Kernif T, Harrat Z, Parola P, Raoult D. Molecular detection of Rickettsia typhi and Rickettsia felis in fleas from Algeria. Clin Microbiol Infect. 2009;15 Suppl 2:255-6.

61. Bitam I, Parola P, De La Cruz KD, Matsumoto K, Baziz B, Rolain JM, et al. First molecular detection of Rickettsia felis in fleas from Algeria. Am J Trop Med Hyg. 2006;74:532-5.

62. Khaldi M, Socolovschi C, Benyettou M, Barech G, Biche M, Kernif T, et al. Rickettsiae in arthropods collected from the North African Hedgehog (Atelerix algirus) and the desert hedgehog (Paraechinus aethiopicus) in Algeria. Comp Immunol Microbiol Infect Dis. 2012;35:117-22.

\section{Submit your next manuscript to BioMed Central and we will help you at every step:}

- We accept pre-submission inquiries

- Our selector tool helps you to find the most relevant journal

- We provide round the clock customer support

- Convenient online submission

- Thorough peer review

- Inclusion in PubMed and all major indexing services

- Maximum visibility for your research

Submit your manuscript at www.biomedcentral.com/submit

) BioMed Central 